\title{
CALENDAR OF EVENTS
}

November 6, 2006. Care of the Stroke Patient will be held in Winnipeg, Manitoba. For further information: email: registration@nursinglinks.ca or find the pdf brochure at http://www.nursinglinks.ca/pdf_stroke3_w.html.

November 7, 2006. Care of the Stroke Patient will be held in Toronto, Ontario. For further information: email registration@nursinglinks.ca or find the pdf brochure at http://www.nursinglinks.ca/pdf_stroke3_t.html.

November 9-12, 2006. 2006 Assembly of the American Academy of Physical Medicine and Rehabilitation will take place in Honolulu, Hawaii. For more information contact Cheryl Ritzi. Email: critzi@aapmr.org or website www.aapmr.org.

November 10-12, 2006. American Headache Society 2006 Scottsdale Headache Symposium will take place in Scottsdale, Arizona. For further information contact (856) 423-0043, fax (856) 423-3420 or e-mail ahsmtgs@talley.com.

November 12-15, 2006. Endoscopic Neurosurgery Workshop - A Training Course for Neurosurgeons and Neurosurgical Nurses will be held in Ghent, Belgium. For more information/registration: www.neuroendoscopy.org.

November 16-18, 2006. International Symposium on Intraoperative Neurophysiological Monitoring in Neurosurgery will be held in New York City, NY, USA. For more information, call (212) 636-3280; Fax: (212) 636-3159; E-mail: marco@neuro physiology.org or visit www.neurophysiology.org.

November 16-18, 2006. European Charcot Foundation Symposium 2006 - Mending the Brain. Stem Cells and Repair in Multiple Sclerosis will take place in Taormina, Sicily, Italy. For more information, contact Ms. Friedrichs Bosmans, Phone: +31 24 3561954; Fax: +31 24 3540920; E-mail:info@charcotms.org.

November 17-18, 2006. Canadian Radiosurgery Society (CaRS) Meeting will be held in Niagara-on-the-Lake, Ontario. For Preliminary Program and Call for Abstracts Link: http:// www.cme.utoronto.ca/PDF/SUR0609.pdf.

December 3-5, 2006. International Conference on Food Contaminants and Neurodevelopmental Disorders will take place in Valencia, Spain. For further information contact Tel: 0034961974670 or Fax: 0034961974598 or email: catedrasg@cac.es or website: www.fundacioncac.es.

February 19-21, 2007. The 3rd Annual Update Symposium on Clinical Neurology will be held in Tel Aviv, Israel. For further information: http://www.neurophysiology-symposium.com.
May 9-12, 2007. Neuroendoscopy 2007 will take place in Paris, France. For further information, visit www.neuroendo2007.com.

May 24-26, 2007. Vocational Outcomes in Traumatic Brain Injury will be held in Vancouver, BC. For further information, visit www.tbicvancouver.com.

June 19-22, 2007. 42nd Annual Scientific Meeting of the Canadian Congress of Neurological Sciences will be held in Edmonton, Alberta, Canada. Contact CCNS Secretariat for more information. Tel: (403) 229-9544 or Fax: (403) 229-1661. Website: www.ccns.org.

June 21-23, 2007. Neuromuscular Disease and Diagnosis will be held in Cleveland, Ohio. For further information, visit www.clevelandandclinicmeded.com/epilepsy07.

June 23-27, 2007. 8th Bi-Annual Congress of the International Stereotactic Radiosurgery Society will be held in San Francisco, California, USA. For more information contact the ISRS Headquarter Secretariat c/o ICEO (+32 27795959 or isrs2007@iceo.be). Website: www.isre2007.org.

June 24-26, 2007. Vocational Outcomes in Traumatic Brain Injury will be held in Vancouver, BC. For further information, visit www.tbicvancouver.com.

June 24-26, 2007. Epileptology: Comprehensive Review and Practical Exercises will take place in Toledo, Ohio, USA. For more information, visit www.clevelandclinicmeded.com/ epilepsy07.

June 27-29, 2007. The 17th International Epilepsy Symposium will be held in Cleveland, Ohio, USA. For further information, visit www.clevelandclinicmeded.com/epilepsy07.

September 6-9, 2007. 1st World Congress on Controversies in Neurology (CONy) will be held in Berlin, Germany. For further information: www.comtecmed.com/cony.

October 17-20, 2007. American Association of Neuromuscular \& Electrodiagnostic Medicine (AANEM) Annual Meeting will be held in Phoenix, Arizona, USA. For further information and registration: www.aanem.org or call (507) 288-0100.

November 8-11, 2007. 5th International Congress on Vascular Dementia will be held in Budapest, Hungary. For further information, visit www.kenes.com/vascular. 